\title{
Management Control and Business Model Innovation in the Context of a Circular Economy in the Dutch Construction Industry
}

\author{
Henk Ruiter *, Frank De Feijter and Koos Wagensveld
}

Citation: Ruiter, H.; De Feijter, F.; Wagensveld, K. Management Control and Business Model Innovation in the Context of a Circular Economy in the Dutch Construction Industry. Sustainability 2022, 14, 366. https:// doi.org/10.3390/su14010366

Academic Editors: Davide Settembre Blundo, Fernando Enrique García-Muiña, Mauro Francesco La Russa, Anna Maria Ferrari and Maria Pia Riccardi

Received: 30 November 2021 Accepted: 27 December 2021 Published: 30 December 2021

Publisher's Note: MDPI stays neutral with regard to jurisdictional claims in published maps and institutional affiliations.

Copyright: (C) 2021 by the authors. Licensee MDPI, Basel, Switzerland. This article is an open access article distributed under the terms and conditions of the Creative Commons Attribution (CC BY) license (https:// creativecommons.org/licenses/by/ $4.0 /)$.
School of Financial and Economic Management, HAN University of Applied Sciences, 6826 CC Arnhem, The Netherlands; frank.defeijter@han.nl (F.D.F.); koos.wagensveld@han.nl (K.W.)

* Correspondence: henk.ruiter@han.nl; Tel.: +31-6156-69479

\begin{abstract}
This study explores how different forms of management control support and enable business model innovation in the context of the principles of the circular economy. Following a qualitative research approach, empirical data is collected from construction companies and governmental organizations in the Netherlands. Building on Simons' four levers of control. This paper illustrates how to balance the intended and emergent strategies via the organization's management control system. According to Simons, the four levers encompass the beliefs systems, the interactive control systems, the diagnostic control systems, and the boundary controls. The empirical findings uncover the beliefs systems and the interactive control systems to be the most relevant levers that enable and drive business model innovation striving for the effective use of materials. Rather than measuring the output with predefined performance indicators, business model innovation in this context is better served by diagnostic controls which evaluate how innovative business models contribute to the organization's mission.
\end{abstract}

Keywords: management control; circular economy; circular business models; business model innovation; sustainable business models; levers-of-control framework; construction industry; The Netherlands

\section{Introduction}

Human economic activities have placed considerable pressure on the limited capacities of global natural systems in recent decades. Traditional business models which have been developed to "create, deliver, and capture value" [1] are mainly based on the make-takedispose rationale, resulting in an enormous waste of resources. These business models are dominated by achieving financial values like growth in profits and sales [2].

Moving beyond the achievement of financial value only, new and sustainable business models contribute to a more sustainable economic system. García-Muiña et al. [3] underline that sustainable business models draw attention to all three pillars of the Triple Bottom line (hereafter TBL). These pillars are the environmental, economic, and social pillar. In other words: sustainable business models strive for achieving multiple values.

Realizing the shift to sustainable business models requires business model innovation. García-Muiña et al. [3] refer to "the transition to a sustainable business model" (p. 6), drawing attention to the organization's strategy of its value proposition. Moreover, several researchers confirm that business model innovation is essential for organizations to ensure their business models are sustainable [4,5]. Achieving multiple values as part of the organization's strategic orientation requires new sustainable business models as the way to realize this.

This paper focuses on management control as the processes by which organizations translate their strategic choices into business model innovation (Figure 1). Management control is relevant to enable business model innovation, both for adjusting existing business models and for establishing new ones. The shift to new and sustainable business models 
for the achievement of multiple values is relevant and meaningful for manufacturing companies, especially for resource- and energy-intensive industries [3]. The current paper presents empirical evidence from the construction industry, which is generally known for the massive use of virgin materials and energy [6], for instance.

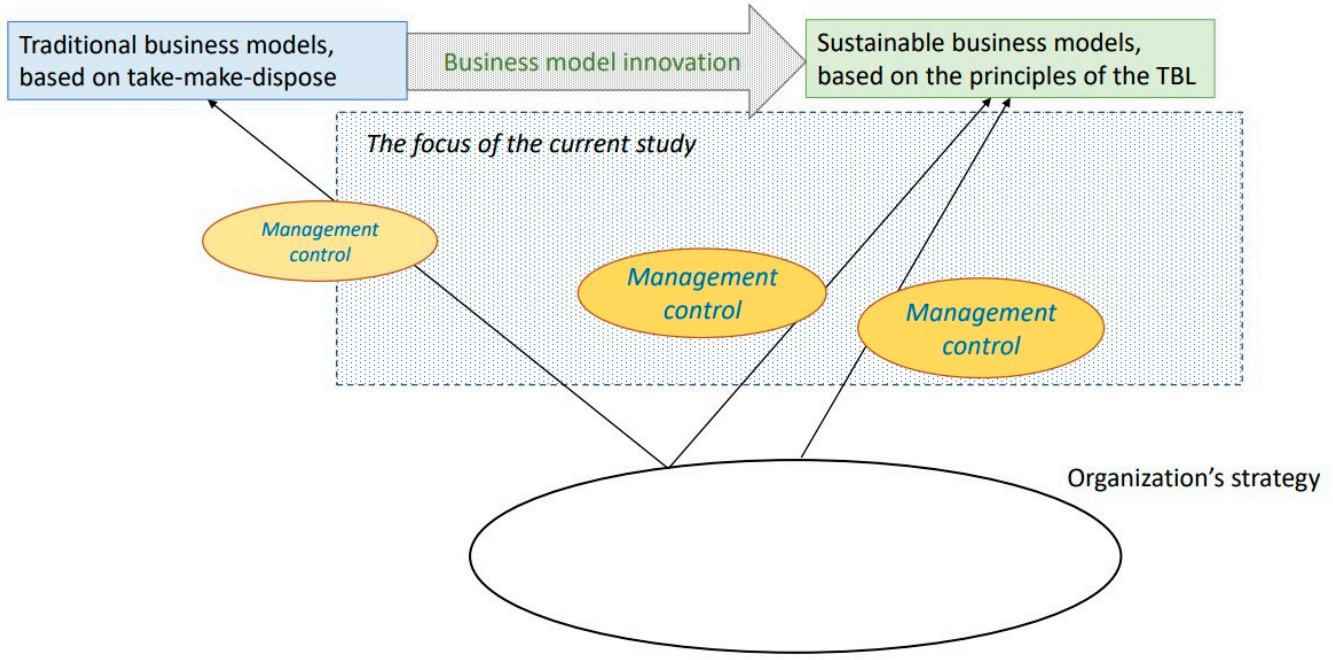

Figure 1. The focus theme of the current study.

Furthermore, we draw on the concept of the circular economy (CE) as this combines sustainable economic growth with reducing the waste of resources, in line with the Ellen MacArthur Foundation [7]. MacArthur et al. [7] challenge the current economic system to achieve "growth from within". The authors provide examples varying from avoiding waste in the construction of buildings to the re-use of materials and the effective use of buildings, illustrating how the CE might contribute to sustainable business models.

In line with García-Muiña et al. [3], we assume that sustainable business models might be realized through the application of the CE-concept and its principles of reuse, recycling, and recovery of materials. Lüdeke-Freund et al. [8] (p. 42) state that innovation in business models is "crucial to allow companies to create value through the implementation of CE principles". Following up on this, the current paper focuses on the multiple value creation by circular business models.

However, it remains unclear how the strategic choice to strive for multiple value creation might drive and direct the innovation of business models. Willekes and Wagensveld [9] note that the common body of literature has not paid much attention to the role of management control with regard to new and sustainable business models. The authors discuss the work of Simons [10] to understand the role of management control in the context of business model innovation.

Simons [10] presents the "four levers of control" (the LoC-framework) to discuss the role of management control in the execution of both the existing strategy and the emergent strategies. On the one hand, highlighting the existing strategy, Simons discusses the diagnostic control systems which are in place to ensure that the existing strategic objectives can be achieved. Translated to the construction context, for example an important aim of management control in the construction industry is to monitor the profitability of individual construction projects. On the other hand, highlighting the emergent strategies, Simons introduces the beliefs systems and the boundary control systems, which aim to challenge and direct organization members in their search for new strategic opportunities. In relation to construction companies, they could for example apply management control systems to support and enable organization members to explore how the use of materials can become more effective. Furthermore, the interactive controls have been developed to enable managers to deal with strategic uncertainties and stimulate creativity and innovation.

This leads to the following research question: 
How can different forms of management control provide a contribution to business model innovation in the context of CE principles in the Dutch construction industry?

The paper's scientific contribution is to present empirical evidence on the relation between management control and business model innovation. In particular, we show how Simons' LoC-framework can contribute to our understanding of business model innovation in the context of $\mathrm{CE}$ and the potential facilitating role of management control. Figure 2 details how the four levers of control are at the heart of this paper.

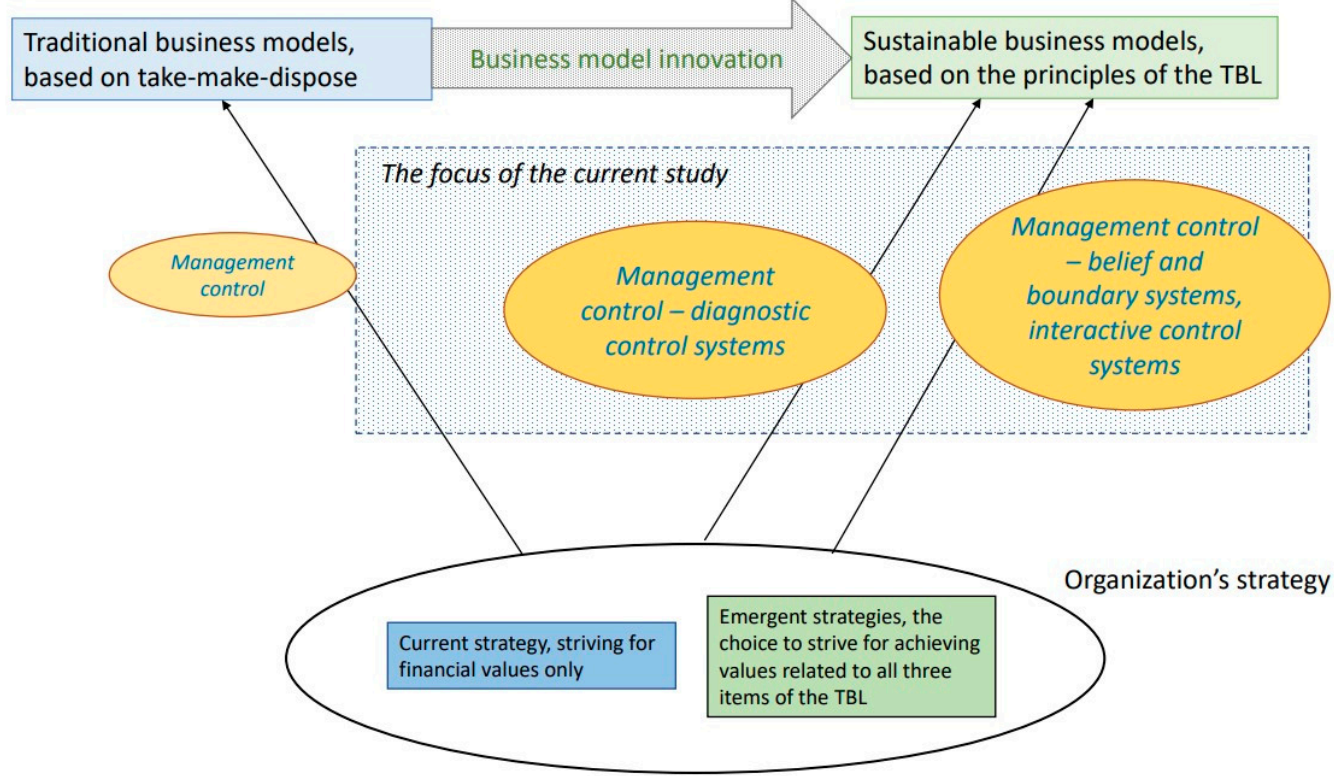

Figure 2. The four levers of control in relation to the focus theme of the current study.

The paper is structured as follows: Section 2 presents the theoretical background, Section 3 details the research approach and provides an overview of the data collection. The findings and results are included in Section 4, followed by the conclusion and discussion in Section 5 .

\section{Theoretical Background}

In this section, we give a brief overview of the literature about the way management control is presented in the LoC-framework and how the LoC-framework might be meaningful in the light of striving for sustainable business models. Moreover, we analyze how each individual lever of control might contribute to business model innovation in a move towards circular business models.

\subsection{Levers of Control Framework}

Emphasizing the role of the organization's management control system when executing the organization's strategy, Simons [10] directs attention to both top-down and bottom-up controls. Top-down controls are typically in use to achieve existing strategic objectives ("the intended strategy") and the bottom-up controls drive the creative search for new strategic opportunities ("emergent strategies"). Strauß and Zecher [11] underline that Simons embraces the perspective of "innovation and control", opposing the prevailing perspective of "command and control", which is at the core of the work by Merchant and Van der Stede [12] and the work of Anthony and Govindarajan [13]. In line with Willekes and Wagensveld [9], we acknowledge that for this reason, the LoC-framework by Simons might be in particular useful to understand the management control to enable the strategic choice for achieving multiple value creation.

More specifically, the LoC-framework aims to balance the controls to stimulate organization members to make the right choices to avoid acting contrary to the organization's 
mission. As such, the LoC-framework provides a valuable and innovative contribution to the mainstream view on management control as the framework deepens our understanding of the role of management control in the strategic objective to achieve multiple values. The LoC-framework has been considered helpful to better understand the balance between achieving different objectives, for example, the balance between social corporate objectives and financial objectives [14,15].

Responding to emerging opportunities and strategic uncertainties is at the heart of management control [16]. Equally important, an organization needs to continue the execution of its current strategy while driving the change to new business models. Simons [10] has acknowledged this duality by introducing the four levers of control to balance emergent strategies with the current intended strategy in one management control system. We now provide a short introduction to each individual lever of the LoC-framework.

- Beliefs systems. According to Simons, a belief system is "the explicit set of organizational definitions that senior managers communicate formally and reinforce systematically to provide basic values, purpose, and direction for the organization" [10] (p. 34). Simons argues that many opportunities to create value are available within the organization external environment. Top management can use beliefs systems to direct the search for new ways of creating value by individual organizational members.

- Boundary systems. In relation to motivating organizational members to explore new opportunities, boundaries are required to direct and control employees in order to search for strategic opportunities in line with the organization's vision. Boundary systems communicate the boundaries that organization members should respect at all times.

- Interactive control systems. Many valuable opportunities for circular business model innovation are currently available [17]. Consequently, selecting the best opportunities is key. According to Simons [10], an organization's top management uses interactive control systems to explore innovative initiatives. These systems include the way top management challenges the company staff to come up with new ideas and to work these out successfully. These interactive control systems function primarily bottom-up and include room for the creativity needed to discover circular business models.

- Diagnostic control systems are designed to monitor if the current strategy is achieved in accordance with the plan. For instance, construction companies use financial performance indicators at the level of individual projects to monitor whether or not and to what extent the company achieves its objectives.

\subsection{Individual Levers of Control}

The remainder of this section presents a proposal of the research direction for each individual lever to create multiple values. Finally, this section provides an overview of the analytical focus points which we utilize to study the contribution of each individual lever control in the innovation towards sustainable, circular business models in the construction industry.

\subsubsection{Beliefs Systems}

Simons [10] points out the role of beliefs systems as formal controls to direct and stimulate creativity in the search for new solutions. Consequently, startups or entrepreneurial companies might be better equipped to be successful in the search for new solutions. Willekes and Wagensveld [9] emphasize that in the context of business model innovation, the belief systems are less formal in nature and they might be subject to change.

The case study by Veleva and Bodkin [18] demonstrates the significance of coalitions between small entrepreneurial companies and large corporations. With regard to the vision of the entrepreneurial companies, they observe that each "had identified a market gap and opportunity often by serendipity and by following their passion for environmental sustainability" (p. 25). The authors claim this passion is part of the "top drive" of the 
entrepreneurial companies; these companies might be considered frontrunners, realizing radical innovative business models.

In contrast to startups, existing companies with a well-defined vision may need to extend their existing vision to include the achievement of multiple values. Frishammar and Parida [19] observe in their case study that several case companies had revised their vision, giving the examples of Volvo Cars and Asko. The authors study the transition towards a circular business model following the revised strategic vision. For instance, concerning Volvo Cars, they highlight the transition to the business model of offering luxury car-sharing services.

Concurrently, several qualitative studies regarding business model innovation towards CE urge that companies have to rethink their business models to align them with circular principles [20], for instance. In other words, a transition needs to take place [17]. A clear vision is crucial within the transition process, as Leising et al. [21] confirm. Based on a clear vision of sustainability in general and on the circular principles in particular, the organization might achieve the shift to circular business models.

Gusmerotti et al. [22] emphasize that a life-cycle perspective is required in this shift. A vision to achieve circular solutions is typically realized in a coalition involving parties with different roles. These coalitions have the goal to ensure a fruitful cooperation between firms over a longer period of time. Frishammar and Parida emphasize that "a circular business model strongly depends on the contributions of others and that focusing solely on one's own firm and customers is insufficient" [19] (p. 18). For instance, material which the supplier used to consider as waste might be reused in an innovative manner. In this sense, the life-cycle perspective and the supply-chain perspective are closely related. The authors compare this to a natural ecosystem. Leising et al. provide a suggestion to improve the cooperation for the construction industry in the Netherlands stating, "This means that financial rewards are connected to the achievement of the collective goal, so that actors involved need each other" [21] (p. 985). Similarly, Pieroni et al. [17] advocate future research expanding beyond organizational boundaries.

In sum, beliefs systems are revealed in this paper as the cornerstone of the management control system to enable the shift to circular business models. Moreover, circular business models are likely to flourish in long-term cooperation in which different partners provide each their specific contribution.

\subsubsection{Interactive Control Systems}

The interactive control systems are closely connected with the beliefs systems as these control systems are important when exploring new business opportunities, based on the organization's vision [10]. Simons points out that the interactive controls are regulated: the bottom-up initiatives have to be approved by management. By contrast, striving for business model innovation achieving multiple value creation, Willekes and Wagensveld [9] urge that interactive control systems are not regulated as these systems have to stimulate and enable the creative search for new opportunities.

Following up on Willekes and Wagensveld [9], we stress that the interactive controls might deliver a valuable contribution to the creative search for innovations as the interactive controls enable communication from innovative initiatives from the bottom-up. De Haan-Hoek et al. [23] confirm that the organization's interactive control system "involves a rich exchange of information, providing the opportunity for organizational learning and possibly discovering both potential risks and opportunities" (p. 6). Illustrating that interactive control systems are closely related to the beliefs systems, Mendoza et al. [24] and Heyes et al. [25] describe how an organization might include tools to take employee initiatives from different organizational levels into account. We underline the meaning of the dialogue between company's employees to discuss emergent strategies and circular business models alike.

Equally important, the interactive use of controls can become manifest in the cooperation with third parties in the exchange of initiatives and the joint effort to realize circular 
business models. Leising et al. [21] draw attention to the role of learning processes in the transition to a circular construction industry in the Netherlands. The authors emphasize the collaboration within the supply chain to stimulate innovation in the context of a construction project (p. 984).

\subsubsection{Boundary Systems}

Boundary systems, according to Simons [10], provide the predefined boundaries to direct and control the search for innovative opportunities. The boundary systems monitor that new initiatives fit into the opportunity space which is determined by the organization's strategic choices. However, striving for innovative solutions, these boundaries are not predefined but they are developed over time.

Additionally, Arjaliès and Mundy [15] point to business conduct boundaries. Based on work by Sarre et al. [26], they suggest that irresponsible behavior by individuals might lead to unacceptable risks for the organization. Ultimately, the organization's reputation might be put at risk. We suggest that codes of conduct might be beneficial to avoid irresponsible behavior.

Following up on Arjaliès and Mundy [15], the current paper understands the role of boundary controls to avoid individual behavior which is adverse to the strategic choice of sustainability. In other words, the boundary systems ensure that the circular business models are aligned with the organization's strategy and mission.

\subsubsection{Diagnostic Control Systems}

First and foremost, the diagnostic control systems are used by an organization to monitor the success of that organization's current intended strategy, according to Simons [10]. As such, diagnostic control systems are in place to measure the output of business processes to compare these to the preset targets and to intervene if necessary. However, in an innovative environment, Willekes and Wagensveld [9] argue that diagnostic controls are less likely to be effective in the absence of preset targets.

We acknowledge that severe difficulties arise to measure if the circular business models are effective and efficient, related to preset indicators. Due to the nature of innovative business models, an organization might not be able to define the exact contribution of new business models a priori. Further, Lüdeke-Freund et al. summarize that "the number of different business models is just too big to be covered in a single typology or to be described in a single research paper" [8] (p. 55). New and different business models might yield different kinds of output, though this might not match with preset indicators in every situation.

However, evaluating circular business models with preset criteria is considered a necessity to scale up new circular business models. Frishammar and Parida conclude the following about scaling up circular business models, "The final phase focused on validating and implementing a circular business model that met the broad goals with respect to financial, environmental, and social benefits. However, precise measurement was often difficult" [19] (p. 23). The Life Cycle Assessment (LCA) is widely used to measure circularity; however, this can be complicated, due to a lack of reliable data [27].

In brief, we tend to consider measuring output in this paper as a future evaluation deliverable rather than a feature that is currently available. The construction industry in the Netherlands lacks generally accepted principles, tools, and techniques to evaluate the contribution of circular business models in measurable items.

\subsection{Towards Analytical Focus Points}

Table 1 provides an overview of the four levers of control by Simons [10] and the present paper's analytical focus points concerning each of the four different levers, based on the findings presented in the recent literature on circular business models. These focus points provide a research direction for presenting and classifying the paper's findings. 
Table 1. Analytical focus points concerning each individual lever of control.

Simons [10], Considering Traditional

Business Models

Regulated. Mainly bottom-up.
Analytical Focus Points in This Study Concerning Circular Business Models

The beliefs systems

- $\quad$ rule over the other levers; the organization's vision and mission form the cornerstone of the management control system;

- drive radical innovations even beyond the frame of existing CE-oriented business models.

The interactive control systems

- $\quad$ are the mechanisms to explore the emergent strategies in the dialogue between organization members;

may be useful for cooperation between partners in a long-term coalition.

The boundary systems

- $\quad$ are meaningful as a code of conduct to direct day-to-day activities;

- help to find the opportunity space to connect the circular business models with the current organization's strategic approach.

The diagnostic control systems

- $\quad$ reveal that measuring output to compare this with preset goals can be problematic;

Measuring output, comparing this with

Diagnostic control systems preset goals, and taking corrective actions if appropriate. support the vision-driven evaluation and discussion to understand how new business models can deliver a valuable contribution.

Note: The bold items in this table are the core components of the analysis in this paper.

\section{Research Approach}

In general, a qualitative research approach is considered appropriate for understanding complex phenomena. As such, in order to explore how management control would be able to support business model innovation, we have chosen to adopt a qualitative research approach to provide a thick description of the context-specific dynamics. This approach proved to be adequate to gain a rich understanding of our research question.

In particular, the research's aim is to explore the role of management control in the context of business model innovation in the infrastructure and road construction industry, which is a specific subsector within the Dutch construction industry. Highlighting business model innovation in this subsector, we invited the construction companies to reflect in an open participatory atmosphere about the themes of sustainability and business model innovation.

The participating construction companies in this research proved to be eager to learn the opportunities to renew their business models. Furthermore, representing a university of applied sciences, we aim to deliver an applied and societal contribution in addition to the scientific contribution. Therefore, we were glad to combine the data collection for the present paper with developing a practical toolkit for management control and business model innovation.

Section 3.1 provides more details about the specific context in which we have collected the empirical data. Subsequently, Section 3.2 discusses the data collection and data analysis.

\subsection{Context of the Empirical Data Collection}

The products delivered by companies in the subsector of infrastructure and road construction can be found in the public space, especially squares, new roads, and asphalt pavements retrofit. Consequently, in the Dutch context, the industry is dominated by 
public projects in which governmental authorities at various levels take up the role of the purchasing organization. We have included the supply-side perspective, represented by various construction companies, and the demand-side perspective, represented by governmental organizations, in our data collection to deepen our understanding within the value-chain.

This context of public procurement in the Netherlands includes the legal requirement that public procurement procedures, including supplier selection, have to be unbiased and fair. The principle of applying a fair scoring rule in the traditional tender process may impact the choice for circular solutions: if circularity is one of the selection criteria in a certain tender, the purchasing organization has to make clear beforehand how circularity will be evaluated in the tender process. Preset indicators are required which might limit the room to introduce radically innovative solutions.

Concurrently, through public procurement practices, the public contractor can choose to what extent the design choices are prescribed in the tender requirements. If all design choices are fixed and prescribed in detail, innovative solutions are hard to achieve. In contrast, if the tender requirements offer room for construction companies to come up with new solutions, circular innovations might be attractive. As a result, practitioners make a call for public contractors to challenge the construction industry in this sense [28].

\subsection{Data Collection and Analysis}

The empirical data comprise sixteen interviews contributing to our understanding of how the management control system facilitates the shift to new business models. The interviews were all semi-structured, leaving room for discussion and unexpected comments by the interviewees. We performed the interviews in three stages during the period between March 2016 and December 2019 as detailed in Appendix A. This paragraph provides some background and a brief methodological account of each of the three stages.

The first stage of the study included eight interviews to discuss how the selected construction companies utilize management control to achieve their strategic objectives. We sent the interviewees an overview of the topics to be discussed prior to each interview. These topics had the aim to explore how the companies respond to threats and opportunities which emerge in their external environment. The topics included strategic opportunities and challenges, also covering the themes of sustainability and innovation. Based on these insights from various subsectors of the construction industry, we chose to narrow our scope to the infrastructure and road construction industry.

Following the choice to limit our scope to the infrastructure and road construction industry, the second interview stage included three interviews with governmental representatives and an interview with a representative of a large construction company. Furthermore, the main themes we discussed in this second stage were related to the effective use of materials and achieving business model innovation. By including the governmental perspective, we were able to explore to what extent coalitions between the construction companies and the government were beneficial to business model innovation.

Finally, the empirical data collection was completed in the third stage by including a frontrunning organization in the construction industry, which will be referred to as "RoadService". RoadService is a construction company in road construction and related engineering activities with around 200 employees. The company is considered a mediumsized organization. Its clients for road construction activities are mainly local authorities, like municipalities and provinces in the Netherlands. RoadService is based at three locations in various parts of the Netherlands.

In recent years, RoadService has shown to be an industry frontrunner by developing an asphalt pavement in which chemical components are replaced by natural ones. RoadService's management aims to develop the contribution to the CE even further. The opportunities for RoadService to develop new circular business models have been discussed in a recent bachelor thesis. For the sake of this paper, we used this bachelor thesis, and one of the researchers attended the thesis presentation at RoadService's headquarters 
and the ensuing discussion. Additionally, we also conducted in-depth interviews with the managing director and a project manager.

All interviews were audiotaped and interview reports were written based on the recordings. We sent an integral interview report or a summary to the interviewees to retrieve their consent. The interview reports, as agreed upon with the interviewees, were analyzed via the software tool Atlas TI. The four levers of control by Simons provided the base for the analysis of the interview data. This enabled us to observe the opportunities for improving the organization's management control regarding each individual lever of control.

\section{Results}

\subsection{Industry Patterns}

Interviewees representing construction companies tended to focus on individual projects, even when we aimed to discuss the impact of strategic uncertainties and opportunities for innovation during the interviews. In particular, we refer to two interviews with construction company's representatives held in 2016 and 2017 in which the interviewees pointed to construction project failures. Unexpected losses caused by individual projects could even threaten the company's financial position. As a result, management control activities were first and foremost directed to avoiding unexpected project failures. The interviewees recalled how some large and well-known construction companies were facing severe difficulties due to losses in an individual project. This industry-specific context may be relevant as industry patterns that can reduce the speed of movement towards new business models.

Against this background, the remainder of this section presents the empirical findings for each individual lever, based on the analytical focus points detailed in Table 1.

\subsection{Belief Systems}

\subsubsection{Cornerstone}

Our empirical data shows how the beliefs systems have a crucial role in the organization's management control system. The organization's vision and mission come to the fore as the driving force for business model innovation. For instance, RoadService's managing director emphasizes that his company strives for long-term goals: RoadService aims to be a frontrunner, driven by the belief that investing in circular innovations will pay off in the end, even though it seems to be hard to overcome industry patterns. We have discussed this more in depth, challenging the managing director to explain what exactly drives the company's vision:

Because we aim to explore, to reach for new boundaries; that's what we are focused on. It's either: this way of thinking is truly part of your DNA or it is not. It is a matter of choice to explore. [ ... ] Moreover, it's because our view is about the long run: if our choices do not pay off this year, this will be the case in the next.

\section{Interview 3D, RoadService managing director}

RoadService's vision and mission focus on the long-term company values rather than striving to maximize financial value in the short run. Following an innovative vision as the cornerstone of the management control system, construction companies may become frontrunners which are needed for a change at the industry level. Typically, innovative solutions would become publicly known to stimulate the application of these solutions in the future. As a result, frontrunners might not achieve the profits needed to compensate the innovation risks they face in every situation.

\subsubsection{Radical Innovations}

Our study shows that an innovative way of thinking is required to pursue a CEoriented vision. Radically new solutions might be even more responsive to the CE principles than proven techniques, though alternative solutions might not fit into the preset 
indicators for circularity. Severe changes in the economy structure are required for the shift towards CE-oriented business models. These changes go far beyond individual projects and individual companies. This requires a coherent vision which is shared by the stakeholders involved in the procurement procedure, aiming to create substantial room for innovation.

In sum, a clear vision on the theme circularity is the driving force for management control in the context of CE principles. This requires an open-minded attitude, ready to embrace new solutions which move beyond the given rules and beyond the existing industry patterns. The municipality representative illustrates how conflicting interests can hamper the CE-oriented procurement:

A group of very outspoken citizens in a certain city area urged the municipality to replace the existing asphalt pavement in their living environment for noise-reducing asphalt pavement, however, the existing asphalt pavement would last for many years.

Interview 2C, municipality's representative

Facing this situation, the municipality might decide to start a tender process including criteria aiming towards the limited use of virgin material for replacing the existing pavement in line with the citizens' opinions. Furthermore, extending the use of the current asphalt pavement would save the use of materials, serving the ideal of sustainability even better.

Interestingly, this example shows the tradeoff the municipality has to make between different values: Referring to the TBL model, the values related to the pillars of profit and planet seem to be at stake. However, also achieving noise reduction represents value as this might increase the quality of the direct living environment, which is related to the pillar of people.

\subsection{Interactive Control Systems}

\subsubsection{Dialogue}

The dialogue between employees from different organizational levels in a construction company may support the organization's vision to become more oriented towards sustainability. The following example highlights the role of the interactive control systems to support an innovation-driven way of thinking. Three senior officers representing a medium-sized construction company reflected on the dialogue as an interactive control supporting the strategy process:

Each year, construction company A organizes a company-wide strategy meeting to reconsider the chosen strategy, assessing the recent risks and discussing relevant developments in the external environment. About twenty of the company's employees join this strategy meeting, they represent various organizational levels varying from the carpenters to the managing director. The annual strategy meeting contributes to continually rethinking the strategic choices from the perspective of a new generation. Company A strives to change the company from the inside, bottom-up, instead of implementing strategy from the top-down. Giving an example of the results of the most recent strategy meeting, company A noted that the organization lacks the knowledge and experience to transfer existing buildings towards a new intended use.

\section{Interview $1 A$, representatives of construction company $A$}

In their move towards business model innovation, construction companies need to be open-minded, combining existing knowledge with exploring new opportunities in cooperation with external stakeholders. We show how construction companies can actively gain understanding and share their knowledge about business model innovation more purposefully to communicate their CE-oriented vision. All in all, the interactive control systems are the building stones for business model innovation, which includes smart adjustments in the existing business models as well as establishing new ones. 


\subsubsection{Coalition}

Interactive controls are uncovered as meaningful in coalitions in which organizations make a joint effort for business model innovation towards the CE principles. Our analysis shows that technical innovations and business model innovations are intertwined in a number of cases in the construction industry. When discussing the opportunities for cooperation between different kinds of organizations, the province representative argues the constraints on the way to CE are more organizational in nature than technical. He underlines the enormous potential of forming coalitions between governmental organizations and private companies:

You [the governmental organization] should stop asking for assurances in the way you used to do; it is more about facing the risks together and sharing the consequences alike. Now, in the current situation, the government tends to transfer every risk to the market; instead government should rather take on the role to control risks.

\section{Interview $2 B$, province representative}

Such coalitions are essential to share the risks connected to the search for new circular business opportunities in the road construction industry. Similarly, the privately owned company representative notes that the cooperation with startups can be important to achieve innovative ambitions (interview 2D).

Working in coalitions between governmental organizations and private companies like startups may result in both technical innovations and innovations in the business model. RoadService's management clearly shows that alternatives that include close cooperation between the public and private organizations can accelerate the change to circular solutions. In other words, if radical innovations do not fit the preset tender requirements, new solutions might be successfully created in coalitions between private and public organizations.

\subsection{Boundary Systems}

\subsubsection{Code of Conduct}

Setting boundaries in the business model innovation in the construction industry becomes apparent in the way construction companies direct business behavior. The conduct displayed by individual employees needs to support the company's CE-oriented ambition. That is to say, all the organization's staff should be motivated and willing to explore the full range of opportunities as long as they truly contribute to the CE. This attitude is crucial when considering business model innovation. We discussed this theme with a sustainability officer serving a large privately-owned construction company:

The company can be regarded as a frontrunner regarding the CE. Our ambition is to change the market as we have shown recently by offering the concept "Road construction as a service". Currently, we develop critical performance indicators (KPIs) that support behavioral choices in line with the CE principles. This approach contrasts with that of public-owned companies which seem to introduce KPIs mainly for the sake of external reporting. They use the CE-related KPIs for shareholder reporting purposes.

Interview 2D, sustainability officer, representing a large privately-owned construction company

A formal code of conduct might contribute to the desired behavioral change towards business model innovation in this example. However, the company mentioned above is still at an early stage in realizing its CE ambitions. At this stage, the boundary systems and related codes of conduct have yet to be developed.

\subsubsection{Opportunity Space}

When exploring new business models, based on Simons [10] we might assume that construction companies would set clear boundaries to direct the search for strategic opportunities, demarcating the "opportunity space". The boundary systems' role is to provide guidance when aligning the new strategic opportunities with current strategic choices. In 
contrast, overviewing the empirical data, we did not come across any such preset boundaries, except the requirement that business models should potentially be able to contribute to the company's profitability.

Construction company $\mathrm{E}$ is a group company belonging to a large, privately owned construction company. Referring to the different forms of construction projects, company E's finance director mentioned that the mother organization had set one basic rule for their group companies: all activities and every individual project should be profitable. Within this boundary, the group companies have the space to explore opportunities:

And it is up to the group company how creative you are: how do you act in cooperation with other market parties? How creative can you be, which alternatives can you think off to get things going?

Interview $1 E$, Finance director representing a large privately-owned construction company

The finance director did not directly refer to CE-driven building projects. However, given this profitability requirement, company $\mathrm{E}$ had recently successfully applied the CE principles in a large construction project. This example illustrates that the boundary control systems need to provide reasonable opportunity space to enable the creative search for opportunities.

\subsection{Diagnostic Control System \\ 4.5.1. Output}

Based on our empirical data, we observe a tension between measuring circularity with clear KPIs and really open innovation that enables new CE solutions. Measuring circularity in individual construction projects based on clear KPIs is quite complicated. In general, quantifying circularity in the construction industry is based on the extent to which non-virgin materials are used in an individual project. However, we have found that there is no uniform way of calculating circularity for concrete projects in the infrastructure and road construction industry [29].

As included in the findings regarding the beliefs systems, an open search for innovations is needed in response to the desired change of the underlying economic system. Measuring circularity with KPIs falls short of supporting this search: due to the open nature of searching for innovations, it is impossible to evaluate these innovations with preset performance indicators that measure circularity within the scope of an individual project or tender. RoadService's managing director confirms this point in his reflection about the efforts RoadService has to make in joining a tender:

Joining a tender in the area of public procurement, RoadService is regularly required to provide lots of information detailing the calculations of the project's circularity. We have to specify and make things measurable ... all for the sake of comparing the proposals made by the various companies. But these requirements do not imply that you solve the problem in a sustainable way.

\section{Interview 3D, RoadService managing director}

Due to the tender requirements which are based on legislation concerning public procurement, innovative solutions may be out of scope at the level of individual building projects. In line with the findings regarding the beliefs systems, the empirical evidence shows that the use of preset KPIs does not support a circularity mindset.

\subsubsection{Evaluation}

Evaluating the development of new business models and analyzing the value created by pilot projects form the main ingredients for a strong diagnostic control system. In this way, these systems can support the radical innovations needed for a frontrunner-role of construction companies when moving towards CE-oriented business models.

We observe, in general, that business model innovations are often designed and developed by startup companies. This also applies to the construction industry. Pilot projects 
were discussed in the three interviews with representatives working at various levels in the government (interviews 2A, 2B and 2C). In sum, many new business models are tested and discussed at this stage in order to select the most promising ones. The selected ones need to be scaled up at the right moment to demonstrate that the business model in question is suitable for further expansion. The representative of the national organization for road construction comments on the right moment to scale up new initiatives (Interview 2A):

Scaling up business model innovation is crucial. It is essential to know who or what is needed to scale up an innovative initiative. Otherwise, no one embraces the innovation and you have to continually explain the same story.

Interview $2 A$, government representative, national level

Similarly, the representative of a large construction company explains how the company actively searches for startups with interesting new business initiatives (interview 2D). In brief, diagnostic control systems need to facilitate the evaluation of business model innovations to understand if, how, and when these initiatives will provide a valuable contribution to the organization's mission.

\section{Conclusions and Discussion}

The common body of literature reveals that business model innovation can contribute to the shift to sustainable business models. However, little research attention has been paid to the relation between management control and business model innovation. The current paper aims to deepen our understanding of this relation, zooming in on circular business models in the construction industry. In particular, the paper's focus is on the effective use of material, in line with the CE principles reuse, recycle and recovering of material. This leads to the following research question: How can different forms of management control provide a contribution to business model innovation in the context of CE principles in the Dutch construction industry? Drawing on a qualitative research approach, we applied Simons' Levers of Control-framework (LoC-framework) [10] to explore the role of management control systems with regard to business model innovation. The four levers of control presented by Simons in 1995 illustrate the role of an organization's management control system, balancing the realization of intended (current) and emergent strategies.

The empirical data we have collected from the Dutch construction industry include numerous examples of diagnostic controls to monitor the financial results of individual projects. The interviews with representatives of construction companies yielded many examples of boundary controls to monitor the realization of financial values. In contrast, circularity and business model innovation proved not to be widely spread yet. Without a strong focus on circularity, construction companies typically continue to stress the role of management control to achieve financial objectives based on existing activities and individual construction projects. These examples illustrate the narrow-minded and conservative view of management control present in the construction industry. In other words: the shift to sustainable business models in the construction industry seems to be in an early stage.

Despite this early stage in the shift to sustainable business models, the empirical data has yielded some interesting cases of construction companies which attempt to apply the CE principles in their business activities. Moving beyond the achievement of financial values only, this study explores how the management control system drives business model innovation to achieve multiple values. The examples provided by the construction industry reflect how the beliefs systems and the interactive control systems enable and support business model innovation. A clear vision on sustainability in combination with the creativity to search for CE-oriented solutions appear to be the drivers for concrete innovations.

Based on the empirical data, we report that the beliefs systems could drive radical innovation by communicating a sound CE-oriented vision. Furthermore, interactive controls could enable the cooperation within and between different organizations to enable a creative search for new business models. Interactive controls might help companies to explore the opportunities for business model innovation, including adjusting existing 
business models. Boundary systems stimulate organization members to act in accordance with the organization's CE-oriented vision.

Typically, the concrete examples to apply the CE principles in construction projects are quite innovative. Due to this innovative nature, the use of circular alternatives in concrete projects might be limited by very detailed tender requirements. Moreover, we line out that business model innovations could be realized in cooperation with startup companies and other organizations with the ambition to contribute to a sustainable economic system. In this context, diagnostic controls would be useful to evaluate the contribution of business model innovations to the organization's mission.

Our findings emphasize the role of beliefs systems concerning the translation of a strategic vision on sustainability to business model innovation in line with the CE principles. Illustrating the role of the beliefs systems from our empirical data, we point to the examples showing how pursuing a CE-oriented vision prevails over short-term financial results. The examples from the construction industry stress that overcoming existing industry patterns might be needed.

Overall, elaborating on Simons [10], we summarize that management control can support business model innovation towards CE principles. The current study presents valuable examples showing how some construction companies strive to apply the $\mathrm{CE}$ principles in their business models. These construction companies seem to be frontrunners; however, their initiatives might invite and challenge other construction companies to reconsider their business models as well.

The key empirical findings for each individual lever are displayed in Table 2:

Table 2. Empirical findings regarding each individual lever of control.

\begin{tabular}{lll}
\hline & $\begin{array}{l}\text { Analytical Focus Points in This Study } \\
\text { Concerning Circular Business Models }\end{array}$ & $\begin{array}{l}\text { The Collected Empirical Examples of Circular } \\
\text { Business Models }\end{array}$ \\
\hline $\begin{array}{l}\text { The beliefs systems } \\
-\quad \\
\text { rule over the other levers; the } \\
\text { organization's vision and mission form } \\
\text { the cornerstone of the management } \\
\text { control system; } \\
\text { drive radical innovations even beyond } \\
\text { the frame of existing CE-oriented } \\
\text { business models. }\end{array}$ & $\begin{array}{l}\text { The examples we have selected from the } \\
\text { construction industry show how } \\
\text { construction companies search for strategic } \\
\text { innovations based on a profound } \\
\text { cornerstone vision on CE. }\end{array}$ \\
& $\begin{array}{l}\text { In these companies, pursuing a radical } \\
\text { long-term CE-oriented vision may prevail } \\
\text { over achieving short-term financial results. }\end{array}$ \\
\hline
\end{tabular}


Table 2. Cont.

Analytical Focus Points in This Study

Concerning Circular Business Models
The Collected Empirical Examples of Circular

Business Models

\section{The interactive control systems}

- $\quad$ are the mechanisms to explore the emergent strategies in the dialogue between organization members;

- may be useful for cooperation between partners in a long-term coalition.
- $\quad$ The findings include an example illustrating that the dialogue between organization members contributes to the renewal of the organization's strategic choices. Moreover, the interactive control systems show how a construction company as a frontrunner searches for the opportunities to achieve its innovative vision.

- Working in a coalition with a startup company is highlighted as a concrete example by two of the selected construction companies.
The boundary systems

- $\quad$ are meaningful as a code of conduct to direct day-to-day activities;

Boundary systems

- $\quad$ help to find the opportunity space to connect the circular business models with the current organization's strategic approach.
- Boundaries are especially meaningful in the context of directing employee's behavior in line with the company's strategy. A formal code of conduct might be useful in this sense.

- Our findings underline that the boundary systems need to facilitate an adequate opportunity space to achieve innovative solutions.
The diagnostic control systems

- reveal that measuring output to compare this with preset goals can be problematic;

Diagnostic control systems support the vision-driven evaluation and discussion to understand how new business models can deliver a valuable contribution.
- One construction company representative noted that comparing output with preset KPIs in individual projects does not stimulate the search for radical innovations which are needed for the shift to circular business models.

- The paper presents examples showing how construction companies evaluate the possibilities for scaling up the innovative solutions introduced by startup companies.

Note: The bold items in this table are the core components of the analysis and empirical data- collection in this paper.

The current paper illustrates how the LoC-framework of Simons [10] can be used to study the relation between management control and business model innovation in the context of sustainable business models. More in particular, our research has explored how management control can support the shift to circular business models in the construction industry.

This paper contributes to the existing literature as we provide empirical evidence for the relation between management control and business model innovation. Specifically, the empirical data from the Dutch construction industry show that, in particular situations, the prevailing industry patterns have to be overcome to enable new and radical innovative solutions. For instance, detailed tender requirements do not provide the necessary room for innovative alternatives.

Moving beyond the existing body of research, this paper might contribute to future research by presenting the analytical focus points to study the role of the management control system in the context of business model innovation. This operationalization of the four levers of control by Simons [10], as displayed in Table 1, may be beneficial for future research on the relation between management control and business model innovation in different settings. We suggest that the business model innovation towards CE principles in this industry is at an early and immature stage. Given this, we show the limitations of 
using diagnostic control systems. The question how diagnostic control systems might be developed over time is therefore open for future research. Possibly, developing specific diagnostic control systems for different kinds of industries might be beneficial to accelerate business model innovation.

Emphasizing that numerous examples of successful circular business models rely on the cooperation between different organizations, Lüdeke-Freund et al. [8] urge that future research on circular business models should aim to deepen our understandings of the cooperation between the various parties in the field. In particular, this study sheds light on the opportunities for cooperation between construction companies and governmental organizations. Regarding the construction industry, our study underlines the role of forming coalitions to support business model innovation, which indicates an interesting area for future research. More in particular, we would call for longitudinal case studies to understand in more depth how management control might support business model innovation.

Author Contributions: Conceptualization, F.D.F. and K.W.; Formal analysis, H.R.; Investigation, H.R.; Methodology, H.R. and F.D.F.; Project administration, H.R.; Supervision, F.D.F. and K.W.; Visualization, H.R. and F.D.F.; Writing—original draft preparation, H.R.; Writing-review and editing, F.D.F. and K.W. All authors have read and agreed to the published version of the manuscript.

Funding: This research received no external funding.

Institutional Review Board Statement: Not applicable.

Informed Consent Statement: Not applicable.

Data Availability Statement: The data are not publicly available due to the fact that involved empirical data comprise the interview reports.

Conflicts of Interest: The authors declare no conflict of interest.

\section{Appendix A}

Table A1. Detailed information on the interviews conducted in 2016 and 2017.

\begin{tabular}{|c|c|c|c|}
\hline & & Interviewees & Date \\
\hline \multirow{3}{*}{$1 \mathrm{~A}$} & \multirow{3}{*}{$\begin{array}{l}\text { Building \& development } \\
\text { company }\end{array}$} & Managing director & \multirow{3}{*}{21 March 2016} \\
\hline & & Controller & \\
\hline & & $\begin{array}{l}\text { Senior employee, responsible for } \\
\text { research \& development }\end{array}$ & \\
\hline \multirow{2}{*}{$1 \mathrm{~B}$} & \multirow{2}{*}{ Road construction industry } & Managing director & \multirow{2}{*}{4 April 2016} \\
\hline & & Finance director & \\
\hline 1BB & & Finance director & 28 August 2017 \\
\hline $1 \mathrm{C}$ & Construction company & Managing director & 6 April 2016 \\
\hline \multirow{2}{*}{$1 \mathrm{CC}$} & & Managing director & \multirow{2}{*}{18 September 2017} \\
\hline & & Project manager & \\
\hline $1 \mathrm{D}$ & $\begin{array}{l}\text { Building \& development } \\
\text { company }\end{array}$ & Controller & 19 April 2016 \\
\hline \multirow{2}{*}{$1 \mathrm{E}$} & \multirow{2}{*}{ Large construction company } & Finance director & \multirow{2}{*}{12 June 2017} \\
\hline & & Project manager & \\
\hline \multirow{2}{*}{$1 \mathrm{~F}$} & \multirow{2}{*}{$\begin{array}{l}\text { Building \& development } \\
\text { company }\end{array}$} & Managing director & \multirow{2}{*}{10 October 2017} \\
\hline & & Finance director & \\
\hline
\end{tabular}


Table A1. Cont.

\begin{tabular}{lll}
\hline & Interviewees & Date \\
\hline $\begin{array}{l}\text { 6 different construction } \\
\text { companies }\end{array}$ & $\begin{array}{l}12 \text { managers and senior employees } \\
\text { contributing to the themes future } \\
\text { proof management control }\end{array}$ & 8 interviews \\
\hline
\end{tabular}

Table A2. Detailed information on the interviews conducted in 2019.

\begin{tabular}{llll}
\hline & Representative & Interviewees & Date \\
\hline 2A & $\begin{array}{l}\text { National department for road } \\
\text { construction }\end{array}$ & national level & 22 March 2019 \\
\hline 2B & Province & regional level & 27 March 2019 \\
\hline 2C & $\begin{array}{l}\text { Purchase department at a } \\
\text { municipality }\end{array}$ & local level & 2 April 2019 \\
\hline 2D & Large construction company & commercial perspective & $\begin{array}{l}\text { 17 April 2019, by } \\
\text { phone }\end{array}$ \\
\hline
\end{tabular}

Table A3. Detailed information on the interviews with RoadService representatives.

\begin{tabular}{llll}
\hline 1A & $\begin{array}{l}\text { Preliminary interview during } \\
\text { internship }\end{array}$ & Interviewees/Attendees & Date \\
\hline 1B & $\begin{array}{l}\text { Preliminary interview during } \\
\text { internship }\end{array}$ & RoadService project manager & 2019 \\
\hline 1BB & $\begin{array}{l}\text { Presentation and discussion of } \\
\text { the bachelor thesis }\end{array}$ & $\begin{array}{l}\text { A group representing both } \\
\text { RoadService staff and } \\
\text { management }\end{array}$ & 12 July 2019 \\
\hline 1C & Final interview & $\begin{array}{l}\text { RoadService managing director } \\
\text { and project manager }\end{array}$ & 13 December 2019 \\
\hline
\end{tabular}

\section{References}

1. Osterwalder, A.; Pigneur, Y. Business Model Generation: A Handbook for Visionaries, Game Changers, and Challengers; John Wiley \& Sons: Hoboken, NJ, USA, 2010.

2. Jonker, J. New Business Models. Working Together on Value Creation; Academic Service: The Hague, The Netherlands, 2014.

3. García-Muiña, F.E.; Medina-Salgado, M.S.; Ferrari, A.M.; Cucchi, M. Sustainability transition in Industry 4.0 and Smart Manufacturing with the triple-layered business model canvas. Sustainability 2020, 12, 2364. [CrossRef]

4. Urbinati, A.; Rosa, P.; Sassanelli, C.; Chiaroni, D.; Terzi, S. Circular business models in the European manufacturing industry: A multiple case study analysis. J. Clean. Prod. 2020, 274, 122964. [CrossRef]

5. Carraresi, L.; Bröring, S. How does business model redesign foster resilience in emerging circular value chains? J. Clean. Prod. 2021, 289, 125823. [CrossRef]

6. Rijksoverheid (Ministerie van Infrastructuur en Milieu \& Ministerie van Economische Zaken). The Netherlands in 2050. Government-Wide Circular Economy Programme; The Hague, The Netherlands. 2016. Available online: https: / / www.rijksoverheid.nl/onderwerpen/circulaire-economie/documenten/rapporten/2016/09/14/bijlage-1-nederlandcirculair-in-2050 (accessed on 28 November 2021).

7. MacArthur, E.; Zumwinkel, K.; Stuchtey, M. Growth Within: A Circular Economy Vision for a Competitive Europe; Ellen MacArthur Foundation: Isle of Wight, UK, 2015.

8. Lüdeke-Freund, F.; Gold, S.; Bocken, N.M.P. A Review and Typology of Circular Economy Business Model Patterns. J. Ind. Ecol. 2018, 23, 36-61. [CrossRef]

9. Willekes, E.; Wagensveld, K. De levers of control en nieuwe businessmodellen: Een exploratieve case study. Maandbl. Voor Account. En Bedriffsecon. 2016, 90, 486-496. [CrossRef]

10. Simons, R. Levers of Control: How Managers Use Innovative Control Systems to Drive Strategic Renewal; Harvard Business Press: Boston, MA, USA, 1995.

11. Strauß, E.; Zecher, C. Management control systems: A review. J. Manag. Control 2013, 23, 233-268. [CrossRef]

12. Merchant, K.A.; van der Stede, W.A. Management Control Systems: Performance Measurement, Evaluation and Incentives, 2nd ed.; Prentice Hall: Harlow, UK, 2007. 
13. Anthony, R.N.; Govindarajan, V. Management Control Systems, 12th ed.; McGraw-Hill: Boston, MA, USA, 2007.

14. Widener, S.K. An empirical analysis of the levers of control framework. Account. Organ. Soc. 2007, 32, 757-788. [CrossRef]

15. Arjaliès, D.-L.; Mundy, J. The use of management control systems to manage CSR strategy: A levers of control perspective. Manag. Account. Res. 2013, 24, 284-300. [CrossRef]

16. Wagensveld, K. How Do Organizations Stay in Control in a Fast-Changing Environment: Inaugural Speech Professor Financial Control. 2016. Available online: https:/ / hbo-kennisbank.nl/details/sharekit_han:Oai:Surfsharekit.nl:8f55e91f-5800-4ea2-9e201bd6a9a9815f (accessed on 24 October 2019).

17. Pieroni, M.P.P.; McAloone, T.C.; Pigosso, D.C.A. Business model innovation for circular economy and sustainability: A review of approaches. J. Clean. Prod. 2019, 215, 198-216. [CrossRef]

18. Veleva, V.; Bodkin, G. Corporate-entrepreneur collaborations to advance a circular economy. J. Clean. Prod. 2018, 188, 20-37. [CrossRef]

19. Frishammar, J.; Parida, V. Circular Business Model Transformation: A Roadmap for Incumbent Firms. Calif. Manag. Rev. 2018, 61, 5-29. [CrossRef]

20. Esposito, M.; Tse, T.; Soufani, K. Introducing a Circular Economy: New Thinking with New Managerial and Policy Implications. Calif. Manag. Rev. 2018, 60, 5-19. [CrossRef]

21. Urbinati, A.; Chiaroni, D.; Chiesa, V. Towards a new taxonomy of circular economy business models. J. Clean. Prod. 2017, 168, 487-498. [CrossRef]

22. Gusmerotti, N.M.; Testa, F.; Corsini, F.; Pretner, G.; Iraldo, F. Drivers and approaches to the circular economy in manufacturing firms. J. Clean. Prod. 2019, 230, 314-327. [CrossRef]

23. De Haan-Hoek, J.; Lambrechts, W.; Semeijn, J.; Caniëls, M.C.J. Levers of Control for Supply Chain Sustainability: Control and Governance Mechanisms in a Cross-Boundary Setting. Sustainability 2020, 12, 3189. [CrossRef]

24. Mendoza, J.M.F.; Sharmina, M.; Gallego-Schmid, A.; Heyes, G.; Azapagic, A. Integrating Backcasting and Eco-Design for the Circular Economy: The BECE Framework. J. Ind. Ecol. 2017, 21, 526-544. [CrossRef]

25. Heyes, G.; Sharmina, M.; Mendoza, J.M.F.; Gallego-Schmid, A.; Azapagic, A. Developing and implementing circular economy business models in service-oriented technology companies. J. Clean. Prod. 2018, 177, 621-632. [CrossRef]

26. Sarre, R.; Doig, M.; Fiedler, B. Reducing the Risk of Corporate Irresponsibility: The Trend to Corporate Social Responsibility. Account. Forum 2001, 25, 300-317. [CrossRef]

27. Manninen, K.; Koskela, S.; Antikainen, R.; Bocken, N.; Dahlbo, H.; Aminoff, A. Do circular economy business models capture intended environmental value propositions? J. Clean. Prod. 2018, 171, 413-422. [CrossRef]

28. CROW Handreiking voor Gemeenten: Duurzaamheid in Projecten en Organisaties [Guidelines for municipalities: Sustainability in Projects and Organizations]. 2018. Available online: https://www.crow.nl/over-crow/nieuws/2018/maart/handreikingvoor-gemeenten-duurzaamheid-in-project (accessed on 17 January 2020).

29. Platform CB'23. Leidraad Meten van Circulariteit. Werkafspraken voor een Circulaire Bouw, Versie 2.0 [Working Instructions for Measuring Circularity, Agreed Working Rules for a Circular Construction Industry, Version 2.0]. 2020. Available online: https: / / platformcb23.nl/aan-de-slag/2020 (accessed on 15 December 2020). 